\title{
Stimulatory Effect of Indole Butyric Acid (IBA) on Cuttings Rooting Response of Olive cv. Gemlik
}

\author{
Muhammad Rafique ${ }^{1}$, Inam U1 Haq ${ }^{1 *}$, Humara Umar' ${ }^{2}$, Muhammad Jan² and Muhammad Azhar Iqbal ${ }^{2}$
}

${ }^{1}$ Barani Agricultural Research Institute (BARI), Chakwal 48800, Pakistan; ${ }^{2}$ Centre of Excellence for Olive Research and Training at BARI Chakwal, Chakwal 48800, Pakistan.

Abstract | In Pakistan, there is a growing interest in olive cultivation, especially in those regions where wild olive groves exist particularly in Punjab (Pothwar), Khyber Pakhtunkhwa and Balouchistan. Few areas of these regions are considered suitable for its commercial cultivation, where minimum temperature occurs between $10^{\circ} \mathrm{C}$ and $12^{\circ} \mathrm{C}$ during end March before olive flowering. In recent past, mass scale olive plantation over an area of 10,000 acres was done in these parts of the country. So, in order to ensure the sustainability of olive orchard development in Pakistan, a research trial was conducted to improve the rooting ability of olive cuttings to strengthen the local olive nursery setup. A practical problem is that the commercial production of potentially important olive cultivars is limited by poor rooting. Therefore, this research was designed to evaluate the stimulatory effect of indole butyric acid (IBA) treatment durations for 5, 10, 15, 20, 25 and 30 seconds by dip method on rooting ability of Gemlik cuttings. The data recorded showed that $\mathrm{T}_{6}(30$ seconds) produced best results for rooting parameters including rooting percent (35.33\%), average number of roots $(8.36)$, average root length $(9.40 \mathrm{~cm})$ and survival rate of olive cuttings $(39.00 \%)$. While poor rooting was observed under $\mathrm{T}_{1}(5$ seconds) with respect to rooting ratio $(19.66 \%)$, average number of roots (1.96), average root length $(3.66 \mathrm{~cm})$ and survival percentage of cuttings $(15.66 \%)$. Resultantly, local nurserymen can produce more number of true to type olive plants for sustainability of olive sector in the country.

Received | March 22, 2021; Accepted | May 11, 2021; Published | June 22, 2021

*Correspondence | Inam U1 Haq, Barani Agricultural Research Institute (BARI), Chakwal 48800, Pakistan; Email: inamulhaq601@gmail.com Citation | Rafique, M., I.U. Haq, H. Umar, M. Jan and M.A. Iqbal. 2021. Stimulatory effect of indole butyric acid (IBA) on cuttings rooting response of olive cv. gemlik. Pakistan Journal of Agricultural Research, 34(3): 533-537.

DOI | https://dx.doi.org/10.17582/journal.pjar/2021/34.3.533.537

Keywords | Olive cultivation, Rooting ability, Nursery setup, Indole butyric acid, Treatment duration, Gemlik

\section{Introduction}

$\mathrm{T}$ he cultivated olive (Olea europaea L.) belongs to family Oleaceae which is among the ancient cultivated fruit plants. It is a perennial, evergreen tree whose cultivation started from Palestine, Lebanon, North West Syria and Cyprus (Jan et al., 2017). Globally, the olive trees are known for their value added products including oil extraction and even in landscape horticulture as ornamental plants (Jan et al., 2017).

The world's largest olive plantation of around 945 million trees exist in Mediterranean region, covering an area of 9.3 million hectares out of 960 million trees; hence, this part of the world comprising about $98 \%$ of total olive plantation (Salari et al., 2017). Whereas in Pakistan, approximately 80 million wild olive trees (Olea cuspidatae) are growing in various parts of the country including Khyber Pakhtun khwa, Pothwar belt in Punjab, Baluchistan, Gilgit Baltistan and Azad Jammu and Kashmir. The existence of such a huge quantity of wild olive groves indicates the possibility for successful olive cultivation in the specific agroclimatic conditions of these areas (Jan et al., 2014). In recent past, commercial olive cultivation started in 
these regions as a result of comprehensive research and development studies of public sector research organizations and more than 10,000 acres of land has brought under olive groves during last five years.

Olive cultivation can be a fundamental element to uplift the economy of any country. Their orchards can be established on fallow, marginal lands having undulating topography, desert ecology and even average soil texture. Being a best carbon sinker, their plantation can overcome the environmental pollution and it also protects the land degradation (Aslmoshtaghi et al., 2014). Keeping in view these characteristics of olive cultivation, major areas of marginal lands in Pakistan especially Punjab are being covered with olive cultivation. Due to its enormous potential in Pakistan, a huge quantity of olive nursery saplings is required to establish new olive groves at mass scale in near future.

Though, none of the cultivated olives are recommended to be multiplied through seeds as the seedling plants bear very less inferior quality fruit and have very long juvenile period. Commercially, olives are propagated from stem cuttings which is among easiest and most widely adopted method for olive nursery raising which favors the speedy nursery production and the new plants start fruiting in early years as compared with seedling plants (Alam and Sajid, 2018).

The major constraint in asexual proliferation of olive is the poor rooting ability of some commercially important cultivars which leads to the undesirable results regarding a successful olive nursery setup (Moshtaghi and Shahsavar, 2011). To overcome this issue, various categories of plant hormones have been discovered which stimulates root growth and development. Presently, auxins have been proved as effective rooting substances in different woody plants. A synthetic auxin called IBA is the best root promoting chemical for olive cuttings. However, in some olive cultivars, this growth regulator remained unable to initiate root primordia and its further development (Fabbri et al., 2004).

Therefore, the present study was designed to investigate the propagation of olive under local conditions of Barani Agricultural Research Institute (BARI), Chakwal, Pakistan to determine the stimulatory response of rooting hormone i.e. IBA for more specific results on the semi-harwood cuttings of cultivar 'Gemlik': A dual purpose variety getting popular in Pakistan due to its wider adaptability.

\section{Materials and Methods}

This research study was conducted in olive nursery situated in Barani Agricultural Research Institute (BARI) Chakwal, Pakistan during 2019-2020. BARI Chakwal is placed at an elevation of $514 \mathrm{~m}$, latitude $32,917^{\circ} \mathrm{N}$ and longitude $72,750^{\circ} \mathrm{E}$. During 2019, $652.8 \mathrm{~mm}$ rainfall was recorded; while in year 2020, a total rainfall of $1833.4 \mathrm{~mm}$ was recorded at the institute. Whereas mean maximum and minimum temperature of $27.5^{\circ} \mathrm{C}$ and $13.8^{\circ} \mathrm{C}$ were recorded in 2019 , and similarly $28.2^{\circ} \mathrm{C}$ and $14.3^{\circ} \mathrm{C}$ in 2020 , respectively.

\section{Selection of cuttings}

The cuttings were prepared from the middle portion of uniformly distributed one year old shoots which were collected from 07-years old olive trees of cv. Gemlik growing in olive multiplication block of BARI Chakwal. For this experiment, uniform, semihardwood cuttings of $22.5 \mathrm{~cm}$ in length and 6-7 $\mathrm{mm}$ diameter thickness having 2-4 leaves at upper part were taken as experimental unit (Hechmi et al., 2013). The research trial was initiated in October, 2019. The potting mix and other cultural practices were kept same for all the experimental plants.

\section{Cutting treatment}

This research experiment was conducted in a lath house having overhead sprinkler system to maintain desirable humidity. The experimental plants/ cuttings were transplanted into ploythene bags of $4 \times 8$ inch size after IBA application. IBA solution at $3000 \mathrm{ppm}$ was prepared by dissolving it in $50 \mathrm{ml}$ ethanol (70\%) and then in distilled water solution. The experimental plant's base was kept in hormonal solution upto $5 \mathrm{~cm}$ according to the following treatments (Table 1 ).

\section{Table 1: Treatments used for IBA dip duration.}

T

$\mathrm{T}_{1}$

$\mathrm{T}_{2}$

$\mathrm{T}_{3}$

$\mathrm{T}_{4}$

$T_{5}$

$\mathrm{T}_{6}$

\section{IBA Dip Duration}

05 seconds

10 seconds

15 seconds

20 seconds

25 seconds

30 seconds 
Data recording

The data was recorded after 120 days of the cutting treatment. In which different parameters like rooting percentage, number of roots per cutting, root length (cm) per cutting and survival percentage of cuttings was recorded. The rooting percentage was recorded as ratio between number of cuttings that developed roots and total number of cuttings. The average number of roots per cutting was measured by calculating total roots produced over total number of cuttings of that treatment. The root length was measured by a scale and the mean was calculated in which roots with half centimeter length were considered for this parameter. While the survival percentage of cutting was also recorded as ratio between successful growth cuttings and total cuttings.

\section{Statistical analysis}

The experiment design for this research trial was completely randomized which having three replications and six treatments with 45 experimental cuttings per treatment. The data was examined statistically by using Statistix 8.1 software and means of the parameters were evaluated according to least significant difference (LSD) test at 5\% probability.

\section{Results and Discussion}

\section{Rooting percentage}

Significant differences were observed among semihardwood cuttings of olive cv. Gemlik at $p<0.05$ in terms of rooting rate (Table 2). Maximum rooting percentage $(35.33 \%)$ was recordedat $\mathrm{T}_{6}$ (30 seconds IBA dip duration) followed by $\mathrm{T}_{5}(25$ seconds) and $\mathrm{T}_{4}$ (20 seconds), which produced $31.66 \%$ and 29.66 $\%$ rooting respectively. While, minimum rooting percentage (19.66\%) was recorded by $\mathrm{T}_{1}$ (5 seconds); and that is conventionally used cutting treatment time of IBA for rooting of olive semi-hardwood cuttings. It might be concluded from these results that both the IBA application and its treatment duration are critical factors to get good rooting response in semi- hardwood cuttings of olive cv. Gemlik. These results are in line with many publications that pointed out IBA as most suitable chemical for root initiation in hard to root olive cuttings (Isfendiyaroglu and Ozeker, 2008).

\section{Average number of roots}

Semi-hardwood cuttings of olive were statistically different from each other $(p<0.05)$ regarding the number of roots per cutting (Table 2). Maximum (8.36) number of roots were produced by $\mathrm{T}_{6}(30$ seconds) followed by $\mathrm{T}_{5}\left(25\right.$ seconds) and $\mathrm{T}_{4}(20$ seconds), which developed 6.16 and 4.96 roots respectively. Contrarily, $\mathrm{T}_{1}$ (5 seconds) produced minimum number of roots i.e. 1.96. The most probable reason to produce more number of roots might be due to the fact that IBA long dip duration has increased cell division and cell elongation concurrently (Ali et al., 2017) as compared to conventional quick dip.

\section{Average root length $(\mathrm{cm})$}

Data recorded in Table 2 showed that IBA dip duration to the olive cuttings for 30 seconds $\left(\mathrm{T}_{6}\right)$ produced longest root $(9.40 \mathrm{~cm})$ among semihardwood cuttings as compared with other treatments $\mathrm{T}_{5}(7.03 \mathrm{~cm}), \mathrm{T}_{4}(5.59 \mathrm{~cm}), \mathrm{T}_{3}(4.78 \mathrm{~cm}), \mathrm{T}_{2}(4.22$ $\mathrm{cm})$ and conventional treatment of IBA i.e. $\mathrm{T}_{1}(3.66$ $\mathrm{cm})$. Similar trend was recorded in mean number of roots and rooting percentage. $\mathrm{T}_{6}(30$ seconds) showed significant high results for mean root number and rooting length which showing a positive interaction between these two parameters. The enhancing effects of IBA on rhizogenesis may be partially due to the action of IBA at the gene level or through enzymatic regulation which cause changes of the normal cell growth program towards root production (Khursheed and Karim, 2005).

\section{Survival percentage}

Observations taken during the survival of the olive cuttings revealed that there was a positive correlation between rooting percent, mean number of roots per

Table 2: Effect of IBA Dip Duration on Rooting Capacity of Olive Cr. Gemlik.

$\begin{array}{lllll}\text { Treatment } & \text { Rooting \% } & \text { No. of Roots } & \text { Root Length (cm) } & \text { Survival \% } \\ \mathrm{T}_{1}(05 \text { seconds }) & 19.66 \mathrm{~d} & 1.96 \mathrm{~d} & 3.66 \mathrm{~b} & 15.66 \mathrm{~d} \\ \mathrm{~T}_{2}(10 \text { seconds }) & 24.33 \pm 1.09 \mathrm{~cd} & 2.33 \pm 0.70 \mathrm{~d} & 4.22 \pm 1.03 \mathrm{~b} & 19.33 \pm 1.40 \mathrm{~cd} \\ \mathrm{~T}_{3}(15 \text { seconds }) & 27.66 \pm 1.17 \mathrm{bc} & 3.93 \pm 0.92 \mathrm{c} & 4.78 \pm 1.07 \mathrm{~b} & 23.66 \pm 2.06 \mathrm{bc} \\ \mathrm{T}_{4}(20 \text { seconds }) & 29.66 \pm 1.20 \mathrm{abc} & 4.96 \pm 0.52 \mathrm{bc} & 5.59 \pm 1.09 \mathrm{~b} & 28.33 \pm 1.40 \mathrm{~b} \\ \mathrm{~T}_{5}(25 \text { seconds }) & 31.66 \pm 1.24 \mathrm{ab} & 6.16 \pm 0.42 \mathrm{~b} & 7.03 \pm 1.06 \mathrm{ab} & 29.66 \pm 1.46 \mathrm{~b} \\ \mathrm{~T}_{6}(30 \text { seconds }) & 35.33 \pm 1.32 \mathrm{a} & 8.36 \pm 0.93 \mathrm{a} & 9.40 \pm 1.10 \mathrm{a} & 39.00 \pm 1.70 \mathrm{a}\end{array}$

September 2021 | Volume 34 | Issue 3 | Page 535 
cutting, mean root length of the cuttings and survival percent during the rooting process (Table 2). As 30 seconds IBA dip duration remained dominant for all these parameters in comparison to other treatments. Consequently, highest survival percentage (39.00\%) was recorded under $\mathrm{T}_{6}$ whereas minimum survival (15.66\%) was observed in conventional $\left(\mathrm{T}_{1}\right) \operatorname{dip}$ duration of IBA for olive cuttings and an ascending order was observed for all parameters with increase in IBA dip duration. The data in Figures 1 to 4 showed that increase in IBA treatment duration from 5 to 30 seconds considerably increased rooting percentage, mean root number, mean root length and their survival in olive cultivar Gemlik in contrast to conventional dip i.e. 5 seconds.

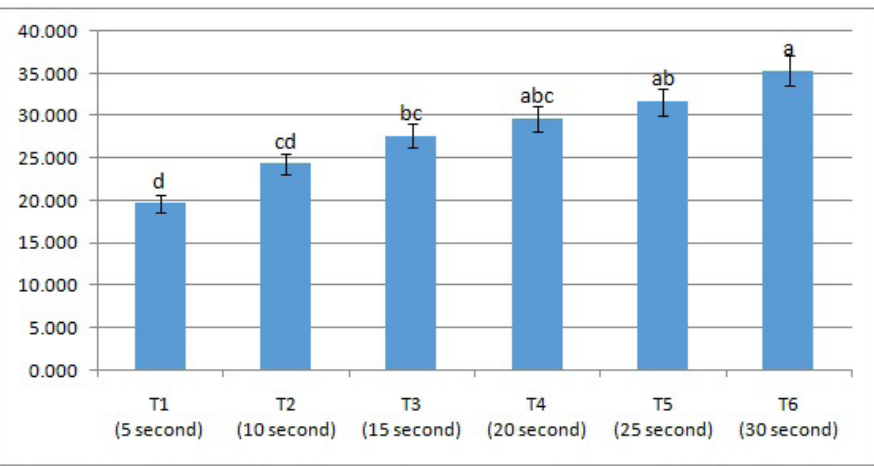

Figure 1: Effect of IBA dip duration on rooting percentage of olive semi hardwood cutting of cv. Gemilk.

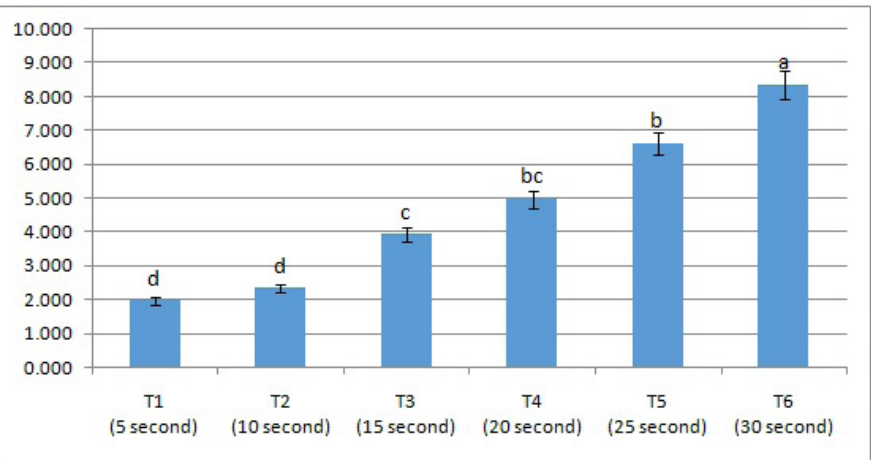

Figure 2: Effect of IBA dip duration on average no of roots of olive hardwood cutting of cr. Gemilk.

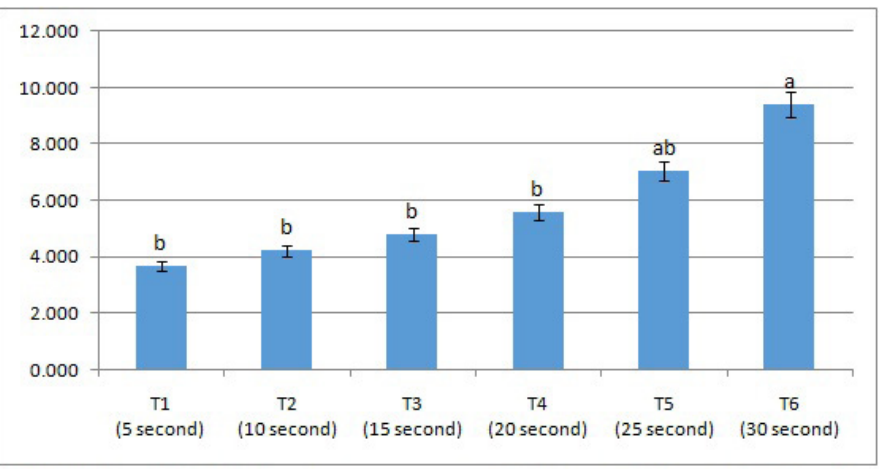

Figure 3: Effect of IBA dip duration on average root length (cm) of olive semi hardwood cutting of cr. Gemilk.

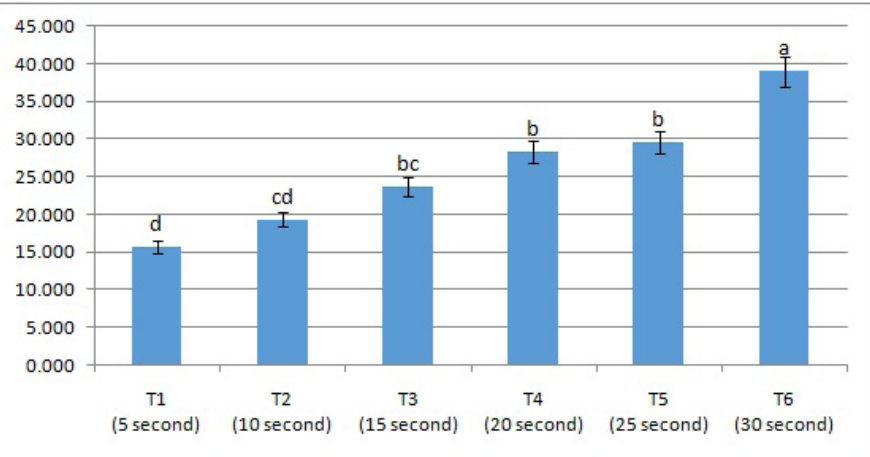

Figure 4: Effect of IBA dip duration on survival percentage of olive semi hardwood cutting of cv. Gemilk.

The highest survival by treating cuttings for 30 seconds IBA dip $\left(\mathrm{T}_{6}\right)$ might be due to more number of roots. While poor success under conventional IBA dips $\left(T_{1}\right)$ is due to less rooting. The similar results were obtained by Alam et al. (2007) during rooting of Kiwi cuttings who stated that vigorous root system improved the uptake of nutrient elements and water from the rooting medium and therefore, it leads to the better survival of cuttings. Secondly, vigorous root system might have produced more carbohydrates and their assimilation required for cuttings survival. The survival of cuttings treated with rooting hormone (IBA) for longer period i.e. 30 seconds might be responsible for the development of root primordia that leads to the elongation of root initials. As these primary roots absorb mineral elements from potting media, which ultimately results in the development of a robust root structure necessary for seedlings survival (Siddiqui and Hussain, 2007).

The present study will help the local nurserymen to improve their protocols for attaining double success of olive plants as compared with conventional method of only 5 seconds IBA dip duration. Therefore, they can produce more number of healthy true to type olive saplings in the light of results obtained during this study. Resultantly, they can provide more plants for sustainability of olive sector in the country.

\section{Conclusions and Recommendations}

Results of the present study revealed that olive cv. Gemlik have displayed an increase of the rhizogenous activity when their cuttings were treated with IBA for longer period (30 seconds) as compared with traditional 5 seconds dip. However, further research is needed to include other rooting substances and study their effect on rooting of cuttings of olive cv. Gemlik. 
Novelty Statement

Olive is a hard to root woody plant specie which is conventionally propagated through cuttings by using IBA dip duration for 5 seconds only. Hence, the overall success rate of nursery plants remained under 20 percent only. However, the olive cuttings treated with IBA for 30 seconds dip recorded maximum survival rate upto 39\% under this study. Therefore, use of IBA dip for more time period prior to olive cuttings plantation should be explored for improvement in Pakistani olive nursery sector.

\section{Author's Contribution}

All authors contributed eqully.

\section{Conflict of interest}

The authors have declared no conflict of interest.

\section{References}

Alam, R. and M. Sajid. 2018. Rooting response of olive cultivars to various cutting types. Sci. Technol. Dev., 37(1): 36-41

Alam, R., K.U. Rahman, M. Iliyas, M. Ibrahim and M.A. Rauf, 2007. Effect of Indole Butyric Acid Concentrations on the Rooting of Kiwi Cuttings. Sarhad J. Agric., 23(2): 293-296.

Ali, M.T., U. Iqbal, R. Mushtaq, E.A. Parray, A. Ibrahim, J.S. Mohiuddin, A.A. Kundoo, I.S. Shah and M.A. Wani, 2017. Effect of Plant Growth Regulators on Rooting of Kiwifruit (Actinidia deliciosa) Cuttings. J. Phar. Phytol., 6(6): 514-516

Aslmoshtaghi, E., R. Shahsavar, A. Reza and M. Taslimpour.2014. Effects of IBA and putrescine on root formation of olive cuttings. Agric. Cons. Sci., 79(3): 191-194.

Fabbri, A., G. Bartolini, M. Lambardi and S. Kailis, 2004. Olive Propagation Manual. CSIRO, Australia. https://doi. org/10.1071/9780643091016

Hechmi, M., M. Khaled, S. Abed, A.E. Hassen, R. Faiez and A. M'hamed, 2013. Performance of olive cuttings (Olea europaea L.) of different cultivars growing in the agro-climatic conditions of Al-Jouf (Saudi Arabia). Am. J. Plant Physiol., 8(1): 41-49. https://doi.org/10.3923/ ajpp.2013.41.49

Isfendiyaroglu, M. and E. Ozeker. 2008. Rooting of Olea europaea Domat Cuttings by Auxin and Salicyclic Acid Treatments. Pak. J. Bot., 40: 1135-1141.

Jan, H., M. Iliyas, I.K. Samar, N. Ali, M.M. Anjum, A. Ullah, R.U. Zahir and M.N. Shuaeb. 2017. Response of rooting of various olive cultivars to IBA (Indole Butyric Acid). Agric. Res. Tech., 9(2): 32-36. https://doi.org/10.19080/ ARTOAJ.2017.09.555757

Jan, I., M. Sajid, A. Rab, A. Iqbal, O. Khan, Y. Jamal, N. Ahmad, A. Ali, M. Shakoor and S.T. Shah. 2014. Effect of various concentrations of indole butyric acid (IBA) on olive cuttings. IFZ . Mitteilungen Klosterneuburg., 64(9): 127-136.

Khursheed, M.Q. and S.A. Karim. 2005. Biochemical changes during rooting period in olive (Olea europaea L. cv. Ashrasi) Cuttings following IBA Application. Letur. J. Dohuk Univ., 8(1): 36-46.

Moshtaghi, E.A. and A.R. Shahsavar. 2011. The effects of IBA and $\mathrm{H}_{2} \mathrm{O}_{2}$ on rooting of 2 olive cultivars. J. Chem. Health Risks., 1(1): 35-38.

Salari, H., B. Baninasab, M. Akbari and M.A. Rohani. 2017. Effect of paclobutrazole on adventitious root formation of IBA-Treated Cuttings of 'Zard' and 'Dakal' Olive (Olea europaea L.) Cultivars. Asian J. App. Sci., 5(4): 692-699.

Siddiqui, M.I. and S.A. Hussain. 2007. Effect of indole butyric acid and types of cuttings on root initiation of ficus Hawaii. Sarhad J. Agric., 23(4): 919. 